\title{
SEGREGATION IN TERMS OF CHEMICAL COMPOSITIONS OF VARIOUS ORDINARY AND REFINED FERROSILICON FRACTIONS FOLLOWING THE PROCESS OF MECHANICAL SHREDDING AND SIEVE CLASSIFICATION
}

\author{
Bolesław MACHULEC ${ }^{1}$, Stanisław GIL², Wojciech BIALIK ${ }^{3}$ \\ Silesian University of Technology, Faculty of Materials Engineering and Metallurgy, \\ Katowice, Poland, EU, \\ 1․oleslaw.machulec@polsl.pl, ${ }^{2}$ stanislaw.gil@polsl.pl, ${ }^{3}$ wojciech.bialik@polsl.pl
}

https://doi.org/10.37904/metal.2019.797

\begin{abstract}
Investigation results for segregation in terms of chemical compositions of various ordinary and refined ultralow carbon FeSi75 ferrosilicon fractions have been presented. The subject of investigations was ferrosilicon obtained under industrial conditions after mechanical shredding and separation on 10-60 mm, 3-10 mm and 0-3 $\mathrm{mm}$ sieves. In addition, specimens of the individual ferrosilicon fractions were sieved on sets of laboratory sieves and fractions with limited granulometric compositions were separated. The investigations have confirmed a high level of elemental segregation in individual fractions, which is related to ingot solidification, a high-temperature range between liquidus and solidus of silicon-based alloys, movement of the solidification front towards zones with decreasing melting points and self-decomposition of silicon-based alloys. The most distinctive differences in chemical compositions between ordinary and refined ferrosilicons refer to light elements with a high affinity for oxygen: $\mathrm{Al}, \mathrm{Ca}$, which is associated with their oxidation during ferrosilicon transfer from the tapping ladle into the refining ladle. It has been confirmed that the mechanism of carbon removal during ferrosilicon refining occurs through floatation of $\mathrm{SiC}$ carbide inclusions in liquid metal bath mediated by $\mathrm{CaO}, \mathrm{Al}_{2} \mathrm{O}_{3}$ oxides.
\end{abstract}

Keywords: Ferrosilicon, submerged arc furnace, refining, chemical composition

\section{INTRODUCTION}

Ferrosilicons FeSi75 and FeSi65 are widely used in the steel industry for steel deoxidation and as alloy additives. As a result of small carbon amounts in new generation steels, there is a higher demand for special types of low carbon ferrosilicon. This requires liquid ferrosilicon processing in a refining ladle with the aim of carbon content reduction from $0.07-0.12 \%$ to below $0.02 \%$. Depending on the temperature, under equilibrium conditions of the binary system $\mathrm{Fe}-\mathrm{Si}$, a few iron-silicon compounds, such as $\mathrm{FeSi}, \mathrm{FeSi}_{2}, \mathrm{Fe}_{3} \mathrm{Si}_{7}, \mathrm{Fe}_{5} \mathrm{Si}_{3}, \mathrm{Fe}_{2} \mathrm{Si}$ and iron matrix-based solid solutions that precipitate during the solidification process, can be found [1,2]. Moreover, industrial-type ferrosilicons contain small amounts of other elements, such as $\mathrm{Al}, \mathrm{Ca}, \mathrm{Mg}, \mathrm{Mn}, \mathrm{Cr}$, $\mathrm{Ti}, \mathrm{P}$ or $\mathrm{S}$, which are usually considered impurities. Their fractions in the chemical composition depend on the quality of raw materials and physicochemical processes that occur during electrothermal reduction of silica with carbon in a submerged arc furnace [3]. For most chemical elements, the solubility limit in solid silicon and ferrosilicon is small and dissolved elements precipitate as inclusions or from intermetallic compounds during solidification. Equilibrium calculations show that almost all carbon contained in FeSi75 appears in the form of solid carbide $\mathrm{SiC}$ inclusions. Carbon solubility in liquid ferrosilicon, in equilibrium with $\mathrm{SiC}(s)$, depends on temperature and decreases at lower temperatures [4-6]. This results in precipitation of secondary $\operatorname{SiC}(s)$ inclusions in the liquid alloy. In addition to silicon carbide, ferrosilicon may contain other carbides of trace elements: $\mathrm{TiC}, \mathrm{CaC}_{2}, \mathrm{Al}_{4} \mathrm{C}_{3}, \mathrm{Al}_{4} \mathrm{SiC}_{4}, \mathrm{MgC}_{2}, \mathrm{Mg}_{2} \mathrm{C}_{3}$. Carbon solubility in silicon is limited but some amounts may dissolve in other phases that are iron-matrix solutions. 


\section{SEGREGATION IN TERMS OF CHEMICAL COMPOSITIONS OF VARIOUS FERROSILICON FRACTIONS OBTAINED IN THE PROCESS OF MECHANICAL SHREDDING AND SIEVE CLASSIFICATION}

Segregation in terms of chemical compositions of ordinary and refined ultra-low carbon (below $0.02 \%$ ) FeSi75 ferrosilicons was investigated. Liquid ferrosilicon was transferred from a 20 MVA furnace into moulding boxes to produce flat, approx. $70-100 \mathrm{~mm}$ thick ingots. After cooling, the ingots were next mechanically shredded and separated on sieves into three fractions: $10-60 \mathrm{~mm}, 3-10 \mathrm{~mm}$ and 0-3 mm. In industry, other technologies of FeSi alloy granulation [7-9] are also frequently applied. In the discussed process, ordinary ferrosilicon was transferred immediately after metal tapping from the furnace. Refined ferrosilicon was transferred from the bottom pour refining ladle following the refining process. The refining process was performed in approximately $8 \mathrm{t}$ ladle. Due to a large capacity of the ladle, refining-intended metal came from two different 20 MVA furnaces with properly synchronized tapping processes. During the refining process, metal was allowed to stand for about 15-20 minutes, which resulted in the upward movement of $\mathrm{SiC}$ carbide inclusions together with $\mathrm{Al}_{2} \mathrm{O}_{3}$ and $\mathrm{CaO}$ oxides and formation of a slag layer on the liquid metal surface. Slag-forming oxides are products of $\mathrm{Al}$ and $\mathrm{Ca}$ oxidation with atmospheric oxygen that occurs when metal is transferred from tapping ladles into the refining ladle. Specimens of individual $10-60 \mathrm{~mm}, 3-10 \mathrm{~mm}$ and 0-3 mm ferrosilicon fractions were sieved on sets of laboratory sieves and fractions with limited granulometric compositions were separated. For measurements of carbon content in the investigated specimens, the LECO CS844 analyzer was used, while contents of the other elements were determined by means of the Perform'X-104 XRF spectrometer (Thermo Fisher ARL). Results of chemical composition investigations for individual fractions of ordinary and refined ferrosilicons are presented in Table 1. Figures 1-4 are graphic representations of silicon, carbon, aluminum and calcium segregation in the investigated specimens. The data presented show that the highest level of segregation is observed in the smallest grain size fraction below $3 \mathrm{~mm}$. Elemental segregation is associated with ferrosilicon solidification, a high-temperature range between liquidus and solidus, differences in the rate and direction of ingot cooling, movement of the solidification front towards zones with decreasing melting points and gravity segregation [6]. Silicon content in liquid decreases with the movement of solidification front and segregation occurs as a result of floatation of $\mathrm{SiC}$ inclusions caused by light elements $\mathrm{Al}, \mathrm{Ca}, \mathrm{Mg}$. Carbide inclusions and other elements float in solidifying liquid and move with the solidification front towards zones with decreasing melting points. Elemental segregation increases with decreasing cooling rate. Low silicon content favors a eutectoid reaction which, consistently with the phase equilibrium conditions in the Fe-Si system, occurs when the silicon fraction is $\sim 54.0 \%$ wt. at the temperature below $937^{\circ} \mathrm{C}[6,10]$ :

$\mathrm{Fe}_{3} \mathrm{Si}_{7} \rightarrow 3 \mathrm{FeSi}_{2}+\mathrm{Si}$

The eutectoid reaction (1) proceeds very slowly but with a volume change and it is believed to influence mechanical strength and self-decomposition of silicon-based alloys. The process of FeSi75 ferrosilicon transfer into ingot molds and the molding box is illustrated in Figure 5 below. Following metal solidification in the ingot, there are conditions for the reaction (1) due to silicon segregation, leading to the poorer mechanical strength of the alloy. As a result, after ferrosilicon shredding and sieve classification, carbide inclusions and trace elements $\mathrm{Al}, \mathrm{Ca}, \mathrm{Mg}$ predominantly accumulate in the $0-3 \mathrm{~mm}$ fine-grained fraction. The most distinctive differences between chemical compositions of ordinary and refined ferrosilicons refer to light elements with a high affinity for oxygen: $\mathrm{Al}, \mathrm{Ca}$ (Figures 3 and 4), which is related to the mechanism of carbide inclusion removal in the process of ferrosilicon refining. A small density difference between liquid FeSi75 ferrosilicon and $\mathrm{SiC}$ carbide practically prevents movement of solid carbide particles upward to the metal bath surface due to the buoyancy force [5]. SiC carbide removal from the metal bath during ferrosilicon refining is mediated by slag-forming oxide inclusions: $\mathrm{SiO}_{2}, \mathrm{Al}_{2} \mathrm{O}_{3}, \mathrm{CaO}, \mathrm{MgO}$. These oxides form as a result of the contact of liquid metal with atmospheric oxygen during furnace tapping and transfer from the tapping ladle into the refining ladle. The slags moisten SiC inclusions and ensure their floatation in liquid ferrosilicon, which helps them move upward to the surface in the refining ladle [5]. 
Table 1 Chemical composition changes for individual fractions of ordinary and refined FeSi75 ferrosilicon following the process of mechanical shredding and sieving

\begin{tabular}{|c|c|c|c|c|c|c|c|c|c|c|c|c|}
\hline \multirow{2}{*}{$\begin{array}{l}\text { Grain } \\
\text { range } \\
(\mathrm{mm})\end{array}$} & \multirow{2}{*}{$\begin{array}{c}\text { Fractio } \\
\text { n } \\
(\mathrm{mm})\end{array}$} & \multicolumn{11}{|c|}{ Chemical composition (wt. \%) } \\
\hline & & Al & $\mathrm{Ca}$ & $\mathrm{Ni}$ & $\mathrm{Ti}$ & C & $\mathrm{Cu}$ & $\mathrm{Cr}$ & $\mathrm{Fe}$ & Mn & $\mathbf{P}$ & Si \\
\hline \multirow{4}{*}{$\begin{array}{c}\text { ordinary } \\
10-60\end{array}$} & $>60$ & 1.51 & 0.270 & 0.038 & 0.123 & 0.053 & 0.110 & 0.018 & 24.4 & 0.196 & 0.023 & 73.2 \\
\hline & $40-60$ & 1.44 & 0.256 & 0.036 & 0.116 & 0.067 & 0.107 & 0.021 & 23.5 & 0.181 & 0.024 & 74.2 \\
\hline & $20-40$ & 1.42 & 0.263 & 0.036 & 0.121 & 0.061 & 0.109 & 0.028 & 23.8 & 0.186 & 0.023 & 73.9 \\
\hline & $10-20$ & 1.47 & 0.282 & 0.036 & 0.116 & 0.113 & 0.110 & 0.019 & 23.1 & 0.182 & 0.023 & 74.5 \\
\hline \multirow{4}{*}{$\begin{array}{c}\text { ordinary } \\
3-10\end{array}$} & $<10$ & 1.55 & 0.346 & 0.035 & 0.123 & 0.138 & 0.109 & 0.015 & 23.3 & 0.188 & 0.024 & 74.1 \\
\hline & $5-10$ & 1.57 & 0.332 & 0.035 & 0.119 & 0.137 & 0.113 & 0.015 & 23.3 & 0.185 & 0.024 & 74.1 \\
\hline & $3-5$ & 1.51 & 0.295 & 0.036 & 0.120 & 0.123 & 0.116 & 0.013 & 23.4 & 0.184 & 0.024 & 74.1 \\
\hline & $<3$ & 1.69 & 0.295 & 0.042 & 0.165 & 0.099 & 0.145 & 0.016 & 26.2 & 0.225 & 0.024 & 71.0 \\
\hline \multirow{3}{*}{$\begin{array}{c}\text { ordinary } \\
0-3\end{array}$} & $>3$ & 1 & 0 & 0 & 0 & 1 & 1 & 3 & 2 & 3 & 0.024 & 74.2 \\
\hline & $1-3$ & 1.64 & 0.302 & 0.037 & 0.131 & 0.125 & 0.118 & 0.016 & 23.9 & 0.191 & 0.024 & 73.5 \\
\hline & $<1$ & 1.79 & 0.3 & 0.037 & 0.140 & 0.112 & 0.120 & 0.015 & 25.3 & 0.204 & 0.0 & 71.8 \\
\hline \multirow{3}{*}{$\begin{array}{l}\text { refined } \\
10-60\end{array}$} & $40-6$ & 0.82 & 0.10 & 0.03 & 0.107 & 0.008 & 0.128 & 0.012 & 24.1 & 0.192 & 0.028 & 74.3 \\
\hline & $20-40$ & 0.79 & 0.087 & 0.038 & 0.104 & 0.011 & 0.132 & 0.015 & 24.6 & 0.198 & 0.028 & 74.0 \\
\hline & $10-20$ & 0.74 & 0.101 & 0.000 & 0.109 & 0.011 & 0.102 & 0.013 & 24.9 & 0.200 & 0.06 & 73.6 \\
\hline \multirow{3}{*}{$\begin{array}{c}\text { refined } \\
3-10\end{array}$} & $5-10$ & 0.84 & 0.117 & 0.038 & 0.106 & 0.008 & 0.131 & 0.017 & 24.2 & 0.195 & 0.028 & 74.2 \\
\hline & $3-5$ & 0.86 & 0.097 & 0.038 & 0.109 & 0.008 & 0.129 & 0.012 & 24.6 & 0.198 & 0.028 & 73.9 \\
\hline & $<3$ & 0.81 & 0.077 & 0.034 & 0.101 & 0.012 & 0.125 & 0.013 & 23.8 & 0.189 & 0.026 & 72.3 \\
\hline \multirow{3}{*}{$\begin{array}{c}\text { refined } \\
0-3\end{array}$} & $>3$ & 0.93 & 0.101 & 0.034 & 0.100 & 0.013 & 0.116 & 0.024 & 24.1 & 0.186 & 0.026 & 74.3 \\
\hline & $1-3$ & 1.05 & 0.113 & 0.037 & 0.111 & 0.021 & 0.129 & 0.027 & 24.6 & 0.199 & 0.026 & 73.6 \\
\hline & $<1$ & 1.26 & 0.147 & 0.038 & 0.122 & 0.045 & 0.131 & 0.019 & 25.5 & 0.211 & 0.025 & 72.4 \\
\hline
\end{tabular}

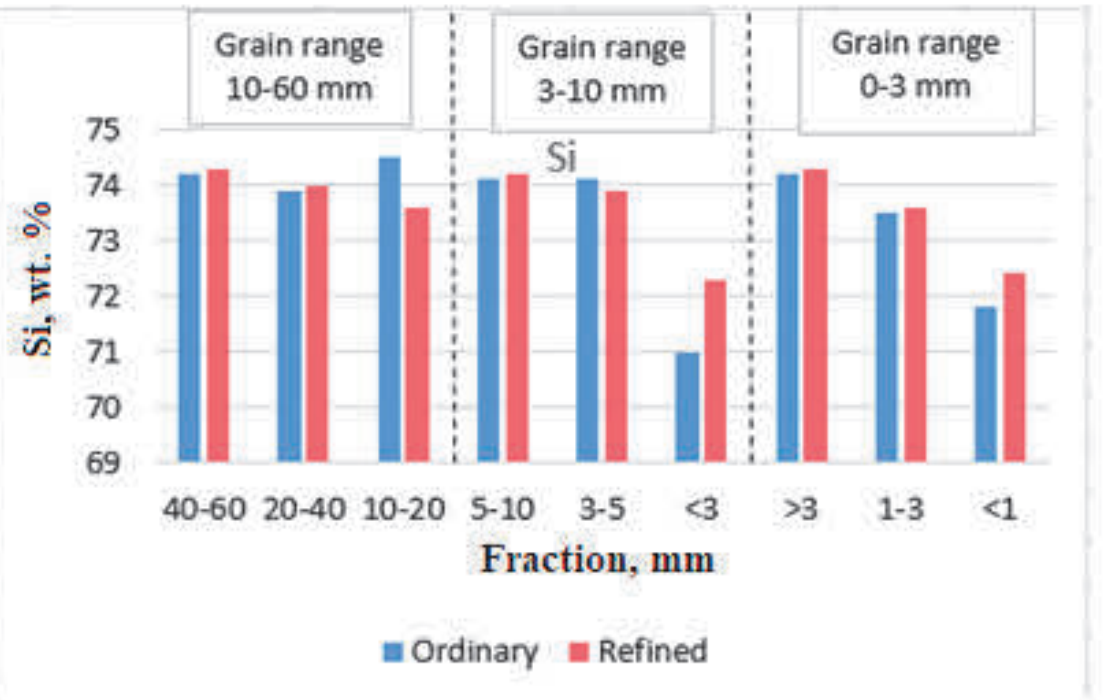

Figure 1 Silicon segregation in individual fractions of ordinary and refined FeSi75 ferrosilicons 


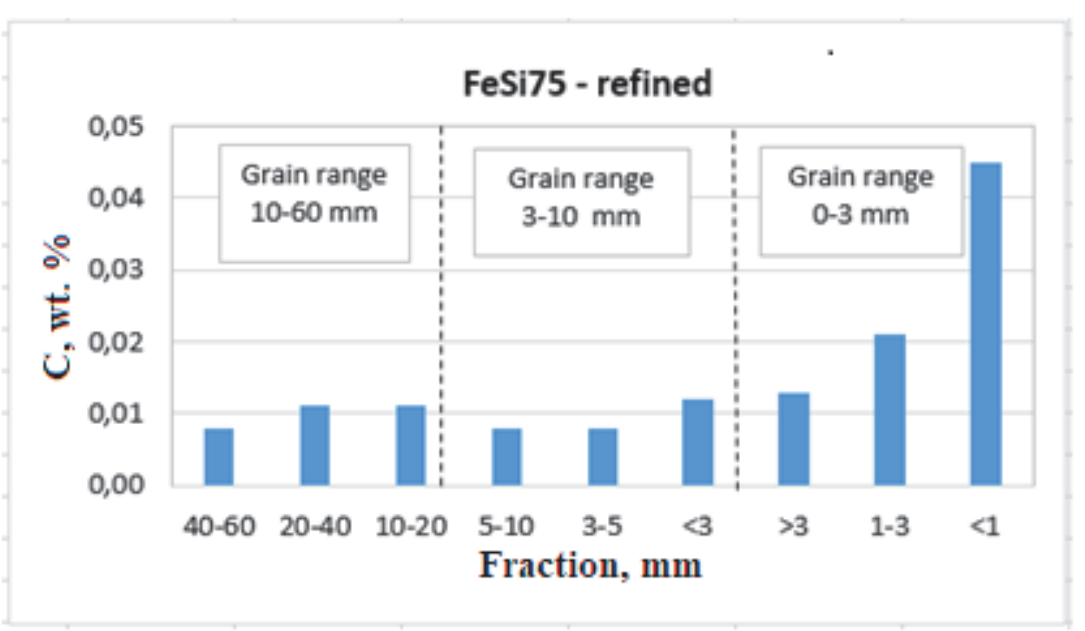

Figure 2 Carbon segregation in individual fractions of refined FeSi75 ferrosilicons

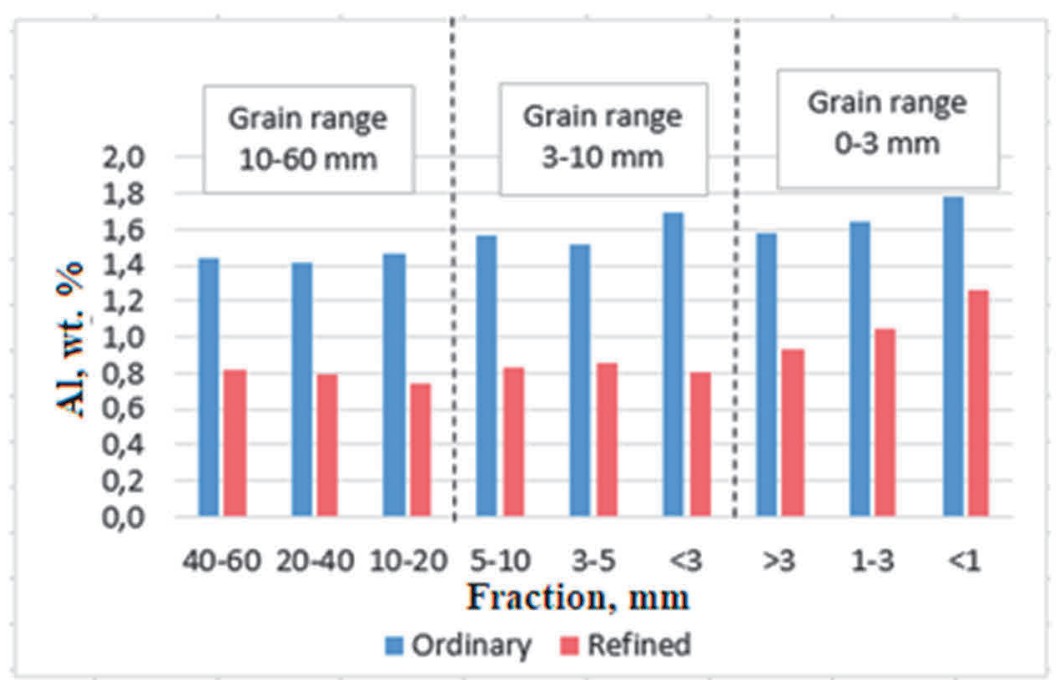

Figure 3 Aluminum segregation in individual fractions of ordinary and refined FeSi75 ferrosilicons

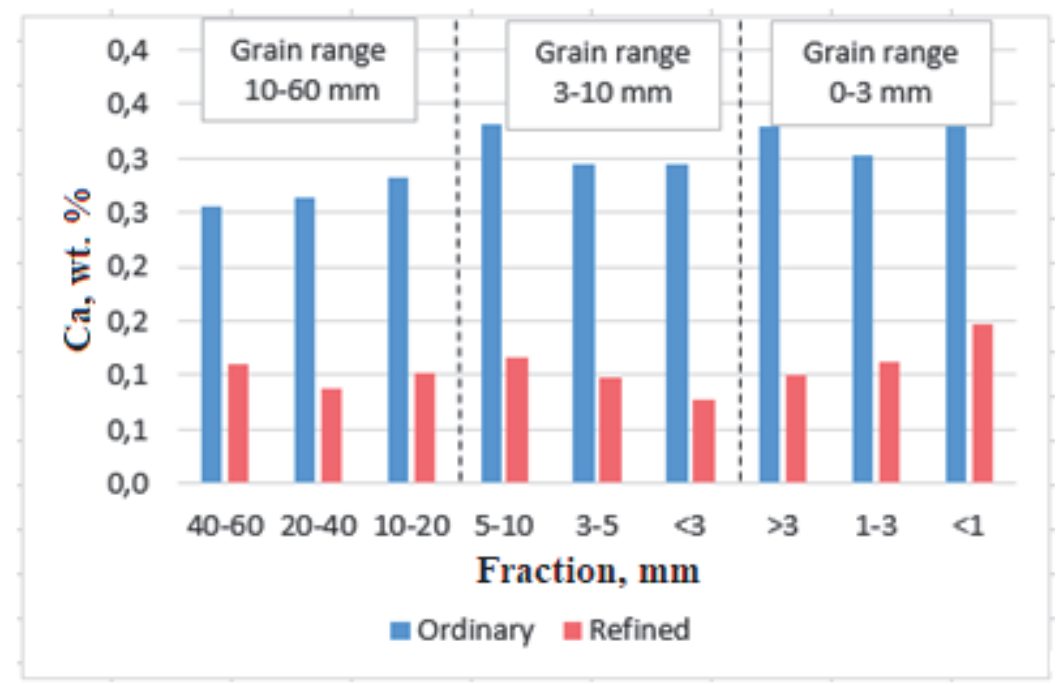

Figure 4 Calcium segregation in individual fractions of ordinary and refined FeSi75 ferrosilicons 

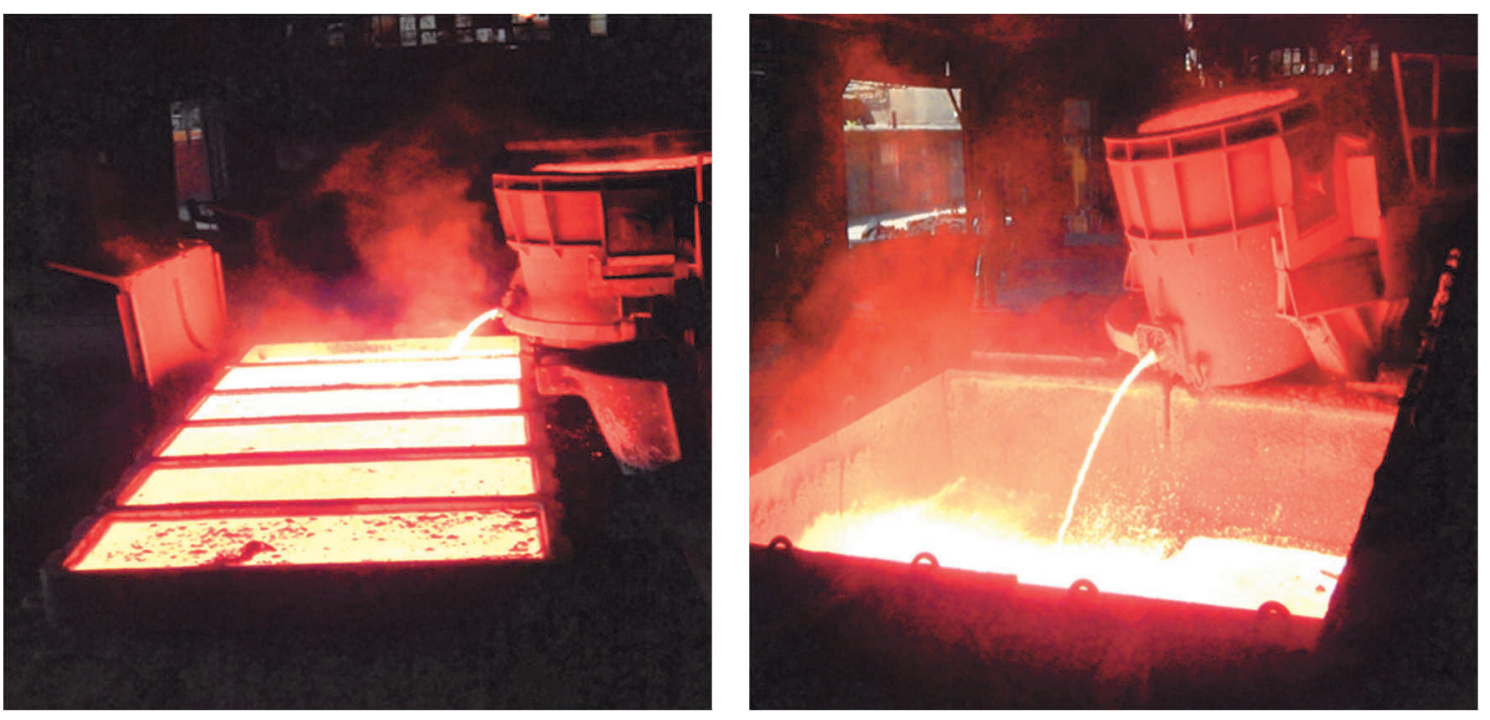

Figure 5 The process of FeSi75 ferrosilicon transfer into ingot moulds and the casting box

\section{CONCLUSIONS}

1) Following the process of mechanical shredding and classification, the highest level of elemental segregation in FeSi75 ferrosilicon is observed in fine-grained (below $3 \mathrm{~mm}$ granulation) fractions. These fractions contain lower quantities of silicon and accumulate impurities i.e. SiC carbide inclusions and trace elements: Al, Ca, Mg. Similar findings were observed by Horn et al. [11].

2) Elemental segregation is associated with ferrosilicon solidification, a high-temperature range between liquidus and solidus, the rate of ingot cooling, movement of the solidification front towards zones with decreasing melting points and self-decomposition of silicon-based alloys.

3) Distinctive differences between chemical compositions of ordinary and refined ferrosilicons refer to light elements with a high affinity for oxygen: $\mathrm{Al}, \mathrm{Ca}$, which is related to their oxidation during ferrosilicon transfer from the tapping ladle into the refining ladle.

4) The process of solid carbon inclusion removal from the metal bath is affected by slag inclusions of $\mathrm{CaO}$, $\mathrm{Al}_{2} \mathrm{O}_{3}, \mathrm{MgO}$ that form as a result of oxidation of the elements contained in the alloy. These slags moisten $\mathrm{SiC}$ carbide and ensure floatation of $\mathrm{SiC}$ carbide inclusions in liquid ferrosilicon.

\section{REFERENCES}

[1] ZUBOV, Viacheslav L. and GASIK, Mihail I. Electrometallurgy of ferrosilicon. Physical Chemistry and Technology. Dnepropetrovsk: System Technologies Publication, 2002.

[2] SCHEI, A.J., TUSET, J. Kr., TVEIT, H. Production of High Silicon Alloys. Trondheim, 1998.

[3] MACHULEC, Bolesław, BIALIK, Wojciech. Comparison the physico-chemical model of ferrosilicon smelting process with results observations of the process under the industrial conditions. Archives of Metallurgy and Materials. 2016. vol. 61, no. 1, pp. $265-270$.

[4] KLEVAN, O.S., ENGH, T.A. Dissolved impurities and inclusions in FeSi and Si, development of a filter sampler. In INFACON VII: 7th International Ferroalloys Congress. Trondheim, 1995, pp. 441-451.

[5] KLEVAN, O.S. Removal of C and SiC from Si and FeSi during ladle refining and solidification. Ph.D. Thesis. The Norwegian University of Science and Technology, Department of Metallurgy, Trondheim,1997.

[6] TVEIT, H., RSSNESS O. The influence of solidification Process of silicon-rich Ferroalloys on product quality. In INFACON V: 5th International Ferroalloys Congress. New Orleans, 1989, pp. 157-167. 
[7] HE, Wenchao, LV, Xuewei, PAN, Feifei, GAO, Leizhang, LI, Xueqin and QIU, Jie. Granulation of ferrosilicon alloy by rotary multi-nozzles cup atomizer: Granulation behavior and model formation. Advanced Powder Technology. 2019. vol. 30, no. 5, pp. 895-902.

[8] HE, Wenchao, LV, Xuewei, LI, Xueqin and QIU, Jie. Granulation of FeSi alloy by rotary multi-nozzles cup atomizer. Materials Science and Technology. Pittsburgh, 2017, pp. 645-651.

[9] LIU, H. Science and Engineering of Droplets. Pittsburgh: William Andrew Publishing, 2000.

[10] SOSNOWSKI, Remigiusz, WYCIŚLIK, Andrzej, PDBIOŁ Stefan, MACHULEC Bolesław. Badanie wpływu składu granulometrycznego na właściwości chemiczne i temperaturę topnienia wybranych frakcji żelazokrzemu o uziarnieniu do 10 mm. Hutnik. Wiadomości Hutnicze. 1987. no. 10, pp. 226-280.

[11] HORN, Q.C., NASSARALLA, C.L., HECKEL, R.W. Microstructural Study of Granulated Ferrosilicon with $75 w t \%$ Silicon. In INFACON VIII: 8th International Ferroalloys Congress. Beijing, 1998, pp.126-132. 